\title{
Agronomic and yield selection of doubled haploid lines of rainfed lowland rice in advanced yield trials
}

\author{
MIFTAHUR RIZQI AKBAR ${ }^{1, \bullet}$, BAMBANG SAPTA PURWOKO ${ }^{2, \bullet}$, ISWARI SARASWATI DEWI ${ }^{3}$, \\ WILLY BAYUARDI SUWARNO ${ }^{2}$, SUGIYANTA ${ }^{2}$, MUHAMMAD FUAD ANSHORI ${ }^{4}$ \\ ${ }^{1}$ Graduate School, Institut Pertanian Bogor. Jl. Raya Dramaga, Kampus IPB, Bogor 16680, West Java, Indonesia. ”email: miftahur.ra@gmail.com \\ ${ }^{2}$ Department of Agronomy and Horticulture, Faculty of Agriculture, Institut Pertanian Bogor. Jl. Meranti, Kampus IPB Darmaga, Bogor 16680, West \\ Java, Indonesia. Tel./fax.: +62-251-8629353, ^^email: bspurwoko@apps.ipb.ac.id \\ ${ }^{3}$ Indonesian Center for Agricultural Biotechnology and Genetic Resources Research and Development. Jl. Tentara Pelajar No. 3A, Bogor 16111, West \\ Java, Indonesia \\ ${ }^{4}$ Department of Agronomy, Faculty of Agriculture, Universitas Hasanuddin. Jl. Perintis Kemerdekaan Km 10, Makassar 90245, South Sulawesi, \\ Indonesia
}

Manuscript received: 28 May 2021. Revision accepted: 28 June 2021

\begin{abstract}
Akbar MR, Purwoko BS, Dewi IS, Suwarno WB, Sugiyanta, Anshori MF. 2021. Agronomic and yield selection of doubled haploid lines of rainfed lowland rice in advanced yield trials. Biodiversitas 22: 3006-3012. Selection process is important step to obtain high yielding variety. This study aimed to obtain information on agronomic performance of doubled haploid lines of rainfed rice in advanced yield trials and select the best lines for multi-location yield trials. Two experiments were conducted in Bogor and Subang using a randomized complete block design for each location and consisted of 35 doubled haploid lines and two check varieties namely Ciherang and Inpari 18 as a treatment. The result revealed that interaction between genotype and environment (G x E) significantly affected all agronomic characters, except on the panicle length. Characters with high heritability value were all agronomic characters except number of productive tillers and productivity. Genotypic correlation analysis showed that number of productive tillers and weight of 1000 grains had significant and positive correlation with productivity. The selection used weighted selection index based on multivariate analysis. Fourteen lines were selected for multi-location yield trials. These lines had characteristics as follows: number of productive tillers (14.0-17.7 tillers), weight of 1000 grains (24.7-32.5 g), and productivity (5.0-6.2 ton ha $\mathrm{a}^{-1}$ ). The selected lines can be evaluated further to obtain superior lines in multi-location trials.
\end{abstract}

Keywords: Anther culture, correlation, high yielding, multivariate selection, superior rice genotype

\section{INTRODUCTION}

Rice becomes one of the most important food sources of calori and has an important role as staple food for half of the world population (Jiang et al. 2020). It is estimated that world population will grow to 8 billion by 2030 (Villa et al. 2012). Rice production must increase around $40 \%$ more by 2030 to satisfy the growing demand without affecting the resource base adversely. Land conversion is one of critical problems, especially in fertile irrigated low land rice, which becomes the main source of rice production in the world and Indonesia.

Globally, rainfed lowland rice contributes around 19\% of the world's rice production from 52 million ha of rainfed lowlands (GRiSP 2013). Rice productivity in rainfed lowland areas is very low (1-2.5 ton ha $\left.\mathrm{h}^{-1}\right)$. Rainfed rice is the second-largest source of Indonesian rice production after irrigated lowland rice. Indonesia has a rainfed area of 3.3 million hectares of rice fields (Ministry of Agriculture 2019) with average of productivity 3.3 tons ha ${ }^{-1}$ (Erythrina et al. 2021). The productivity of rainfed rice is lower than irrigated rice which produces 5.3 tons ha $^{-1}$ (Ministry of Agriculture 2019). The factors causing low productivity of rainfed rice are poor application of advanced cultivation techniques, majority of varieties planted are still local varieties or old superior varieties, less intensive weed control, pest and disease disturbances, and low soil fertility. The development of high-yielding rainfed rice varieties is an alternative to increase productivity.

The breeding of rainfed rice varieties using anther culture techniques is an alternative solution to accelerate the acquisition of pure lines. The formation of pure lines in conventional breeding requires 6-8 generations to conduct selection until the obtainment of pure lines (Dwivedi et al. 2015; Dewi et al. 2017). Application of anther culture method can accelerate the process to obtain pure lines in first-generation (Mishra et al. 2015). The lines resulting from the anther culture have high diversity between lines, thus it is necessary to characterize them to see the initial agronomic information and test the yield potential in the field. The yield trial in the field consists of the preliminary yield trial (Akbar et al. 2019) with characteristics of narrow plot and large number of lines, then continued with the advanced yield trial which has a wider plot and fewer lines. Advanced yield trial is conducted at several locations to see the performance consistency of a genotype.

The appropriate selection criteria will give the maximum result to obtain superior lines in plant breeding program. Productivity can be selected directly as main selection character (Abhilash 2018). However, many 
factors influence productivity so that it is better to use indirect selection which correlates with productivity (Silva et al. 2016; Akbar et al. 2018; Al-kordy et al. 2019; Anshori et al. 2019). Selection index becomes alternative selection method for several characters (Islam et al. 2017; Akbar et al. 2019). The value of selection index is determined by setting the weighting of each character according to its economic value (Cui et al. 2020). The determination of selection characters and character's weighting coefficient can use multivariate analysis (Sabouri et al. 2008; Hasan et al. 2016; Kose et al. 2018; Anshori et al. 2019; Fadhli et al. 2020; Farid et al. 2021). Multivariate analysis can be used for multi variables so interpretation can be done easier (Janmohammadi et al. 2014). This experiment aimed to obtain information on the agronomic performance of the doubled haploid lines of rainfed rice in advanced yield trials and selecting the best lines for multi-location yield trials.

\section{MATERIALS AND METHODS}

\section{Plant materials}

Thirty-five doubled haploid lines derived from anther culture were evaluated and two check varieties, namely Ciherang and Inpari 18 were used. Those lines were advanced lines from selection in preliminary yield trial (Akbar et al. 2019). The selected lines used were obtained from the first generation of cross-breeding population (F1) anther culture plants from five cross-breeding populations.

\section{Procedures}

The experiments were conducted from November 2017 to April 2018 in Bogor (6³3'47.9" S, 10644'10.8” E) with altitude is $180 \mathrm{~m}$ above sea level (ASL) and Subang (6²1'15" S, 107 $38^{\prime} 52^{\prime}$ " E, $13 \mathrm{~m}$ ASL). A randomized complete block design with three replications was used in each location. The size of experimental unit was $3 \mathrm{~m} \times 3 \mathrm{~m}$. Twenty-one-day-old seedlings were planted with plant spacing of $25 \mathrm{~cm}$ x $25 \mathrm{~cm}$. Dosage of fertilizers were 200 , 100 , and $100 \mathrm{~kg} \mathrm{ha}^{-1}$ Urea, SP 36, and $\mathrm{KCl}$, respectively. The SP 36 and $\mathrm{KCl}$ fertilizers were applied one week after planting (WAP), meanwhile, $\mathrm{N}$ fertilizer was applied three times, at 1 WAP, 4 WAP, and 7 WAP one-third each. Pest and disease control was conducted according to standard rice cultivation (IRRI 2015). The observation variables were plant height which was measured at generative stage $(\mathrm{cm})$, number of productive tillers was observed prior to harvesting, day to flowering was observed when $50 \%$ of plants in each plot showed flowering, day to harvesting was observed when $80 \%$ plant of rice panicles in one plot turned yellow, panicle length $(\mathrm{cm})$ was observed after harvesting, number of filled grains per panicle, number of unfilled grains per panicle, number of total grains per panicle, weight of 1000 grains (g), and productivity was obtained from conversion from weight per plot to dry grain yield per hectare (ton ha-1).

\section{Data analysis}

The observed data were subjected to combined variance analysis. Then, the analysis was continued by determining the heritability value (Nirmaladevi et al. 2015) and analyzing the phenotypic correlation and genotypic correlation (Oladosu et al. 2018). Selection index was determined by using weighting value obtained from principal component analysis. Standardization of each character was determined (Jolliffe and Cadima 2016) before principal component analysis. Determination of the character selection was based on components that greatly affected the character of productivity. The vector contained in the component variable was used to weight the selection characters in the selection index. Then, the doubled haploid rice lines were selected. The software used in the analyses were STAR 2.0.1 from IRRI for analysis of variance, Microsoft Excel 2019, and META-R from CIMMYT 2016 for phenotypic and genotypic correlation. The explanation of the analysis carried out was as follows:

Prediction of broad-sense heritability $\left(h^{2}\right)$ was calculated through the formula as follows (Syukur et al. 2015):

$$
\mathrm{h}_{\mathrm{bs}}^{2}=\frac{\sigma_{\mathrm{g}}^{2}}{\sigma_{\mathrm{p}}^{2}}
$$

Where: $\sigma^{2}$ was the genotypic variance, $\sigma_{p}^{2}$ was the phenotypic variance, and $h^{2}$ was the broad sense of heritability. Broad sense heritability was categorized according to Nirmaladevi et al. (2015) as: high $\left(0.50 \leq \mathrm{h}^{2}<\right.$ $1.00)$, moderate $\left(0.20 \leq h^{2}<0.50\right)$, and low $\left(h^{2}<0.20\right)$. The calculation of genotypic coefficient of variation (GCV) followed the formula of:

$$
\mathrm{GCV}=\frac{\sqrt{\sigma_{\mathrm{g}}^{2}}}{\bar{x}} \times 100 \%
$$

Where: ${ }^{\sigma_{\mathrm{g}}^{2}}=$ genotypic variance, ${ }^{\bar{x}}=$ mean, GCV were grouped according to Abebe et al. (2017) as low $(\mathrm{GCV}<0.25)$, moderately low $(0.25 \leq \mathrm{GCV}<0.50)$, moderately high $(0.5<\mathrm{GCV}<0.75)$, and high $(0.75 \leq$ GCV).

Correlation analysis aimed to evaluate the closeness of relationship between characters. Analysis of the genotypic and phenotypic correlation coefficients were calculated by the following formula (Oladosu et al. 2018):

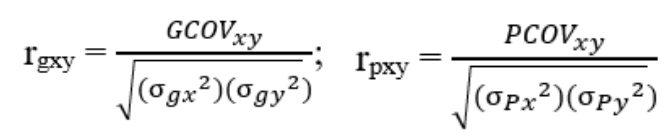

Where: $r_{\text {gxy }}$ was genotypic correlation coefficient between traits $\mathrm{x}$ and $\mathrm{y}, \mathrm{r}_{\mathrm{Pxy}}$ was phenotypic correlation coefficient between traits x and y, GCOV $V_{x y}$ was genotypic covariance between variables $\mathrm{x}$ and $\mathrm{y}, P C O V_{x y}$ was phenotypic covariance between variables $\mathrm{x}$ and $\mathrm{y}, \sigma \mathrm{p}_{\mathrm{x}}{ }^{2}$ was phenotypic variance of variables $\mathrm{x}, \sigma \mathrm{p}_{\mathrm{y}}{ }^{2}$ was phenotypic variance of variables $y, \sigma g_{x}{ }^{2}$ was genotypic variance of variables $\mathrm{x}, \sigma \mathrm{g}_{\mathrm{y}}{ }^{2}$ was genotypic variance of variables $\mathrm{y}$.

Standardization formula was according to Jolliffe and Cadima (2016) as follow: 


$$
Z_{i j}=\frac{\left(\mathrm{x}_{\mathrm{ij}}-\overline{\mathrm{x}} \mathrm{i}\right)}{\mathrm{S}_{\mathrm{i}}}
$$

Where: $Z_{i j}$ was standardized value of the $j^{\text {th }}$ genotype in the $i^{\text {th }}$ character, $X_{i j}$ was observation data of the $j^{\text {th }}$ genotype on the $i^{\text {th }}$ character, $\overline{\mathrm{X}} \mathbf{i}$ was mean of the observed data in the $i^{\text {th }}$ character, $S_{i}$ was standard deviation of the $i^{\text {th }}$.

Selection index determination followed Sandhu et al. (2019) formula, i.e. $I=b_{1} X_{1}+b_{2} X_{2}+b_{3} X_{3}+\ldots . .+b_{n} X_{n}$. where I was selection index, $b_{n}$ was the weight of the variable to $n$, and $X_{n}$ was a standardized phenotypic value for variables to $n$.

$$
\mathrm{Xn}=\frac{(X i j-\overline{X i})}{S i}
$$

Where: $X_{n}=$ standardization value, $X_{i j}=$ means of each genotype, $\overline{\mathrm{X}} \mathbf{i}=$ means of the variable, $S_{\mathrm{i}}=$ standard deviation of the variable.

\section{RESULTS AND DISCUSSION}

\section{Agronomic character, variance component and heritability}

Combined variance analysis showed that genotype $(\mathrm{G})$ had a significant effect on all observed characters (Table 1). This showed that the characteristics of each genotype were different. Environment (E) had a significant effect on all agronomic characters, except on the number of filled grains per panicle. The interaction between genotype and environment ( $\mathrm{G} \times \mathrm{E}$ ) significantly affected all agronomic characters, except on the panicle length (Table 1). Ogunbayo et al. (2014) obtained similar results that the interaction of $\mathrm{G} \times \mathrm{E}$ was significant on the characters of plant height, days to flowering, day to harvesting, number of panicles per hill, and yield. In general, characters that had significant $G \times$ E interactions showed that the genotype responded differently to different environmental conditions, especially among the adapted genotypes and sensitive genotypes (Konate et al. 2016; Anshori et al. 2019; Farid et al. 2020). Therefore, these characters could become selection character candidates in creating the selection index formula.
The genotypic coefficient of variance (GCV) was shown that the number of unfilled grains per panicle had the highest GCV (29.9\%) (Table 2). On the other hand, the lowest GCV was found in day to harvesting (DAS) (2.8\%). As for the yield as the main character also had a low GCV (3\%). Tuhina-Khatun et al. (2015) also reported this result, who obtained a low GCV value in day to flowering and day to harvesting. However, the productivity was categorized as moderate GCV. The characters with low GCV indicated that the character had short interval variance among genotypes (Abebe et al. 2017). However, the GCV value had to be combined with the heritability value. This combination could be a good consideration in line selection.

The genetic parameters like heritability and genotypic coefficient of variation (GCV) were shown in Table 2. Based on this table, the characters with high heritability values were plant height (0.91), days to flowering (0.71), days to harvesting $(0.65)$, panicle length $(0.80)$, number of filled grains per panicle $(0.84)$, number of unfilled grains per panicle $(0.75)$, number of total grains per panicle (0.86), and the weight of 1000 grains $(0.86)$. The character with moderate heritability value was number of productive tillers (0.35), meanwhile, the yield was categorized as low heritability. The high heritability of plant height, number of productive tillers, days to flowering, days to harvesting and weight of 1000 grains also had been reported by Seyoum et al. (2012) and Ogunbayo et al. (2014). In general, the broad-sense heritability was influenced by both the genetic and phenotype variance. The high heritability value could increase effectiveness of selection. Hence, the high heritability can reflect the genetic expression potential of lines toward their phenotype. In doubled haploid plants, broad-sense heritability had the same value as narrowsense heritability due to the homozygous genetic constitution (Dwivedi et al. 2015), so this was beneficial in detecting character selection of doubled-haploid rice. However, based on this result, the yield had low heritability. It supports the GCV result, where direct selection based on the yield was not effective. Therefore, simultaneous selection using several characters was a good alternative method in this study.

\begin{tabular}{|c|c|c|c|c|}
\hline \multirow{2}{*}{ Traits } & \multicolumn{3}{|c|}{ Mean square of } & \multirow{2}{*}{$\begin{array}{l}\text { Coefficient of } \\
\text { variation }(\%)\end{array}$} \\
\hline & Genotype (G) & Environment (E) & G x E Interaction & \\
\hline Plant height $(\mathrm{cm})$ & $1854.8 * *$ & $14786.5^{* *}$ & $169.2 * *$ & 4.01 \\
\hline Number of productive tillers & $8.9 * *$ & $699.97 * *$ & $5.8^{*}$ & 11.87 \\
\hline Day to flowering (DAS) & $184.0 * *$ & $1621.6^{* *}$ & $52.7 * *$ & 1.52 \\
\hline Day to harvesting (DAS) & $97.4 * *$ & $764.6^{* *}$ & $34.5^{* *}$ & 1.61 \\
\hline Panicle length $(\mathrm{cm})$ & $27.9 * *$ & $153.5^{* *}$ & $5.5 \mathrm{~ns}$ & 8.08 \\
\hline Number of filled grains/panicle & $5467.4 * *$ & $6669.9 \mathrm{~ns}$ & $888.9 *$ & 14.24 \\
\hline Number of unfilled grains/panicle & $7.9 * *$ & $115.5^{*}$ & $1.8^{*}$ & 15.73 \\
\hline Number of total grains/panicle & $10526.0 * *$ & $56193.0 *$ & $1424.0 * *$ & 12.40 \\
\hline Weight of 1000 grains $(\mathrm{g})$ & $27.4^{* *}$ & $330.8 * *$ & $3.8 * *$ & 3.80 \\
\hline Productivity (ton ha ${ }^{-1}$ ) & $0.1^{*}$ & $1.0^{*}$ & $0.1 *$ & 9.90 \\
\hline
\end{tabular}

Table 1. Combined analysis of variance for agronomic traits

Note: DAS: day after sowing; $* *=$ significantly different at $\alpha 0.01 ; *=$ significantly different at $\alpha 0.05 ;$ ns $=$ not significantly different at $\alpha 0.05$. 
Table 2. Mean, population range, variance component, and broad-sense heritability for agronomic traits

\begin{tabular}{|c|c|c|c|c|c|c|c|}
\hline Traits & Mean \pm S.D. & $\begin{array}{l}\text { Population } \\
\text { range }\end{array}$ & $\sigma_{p}^{2}$ & $\sigma^{2} g$ & $\begin{array}{l}\text { GCV } \\
(\%)\end{array}$ & $\begin{array}{l}\text { PCV } \\
(\%)\end{array}$ & $\mathbf{h}^{2}$ \\
\hline Plant height $(\mathrm{cm})$ & $114.3 \pm 17.3$ & $83.2-140.7$ & 309.1 & 280.9 & 14.7 & 15.4 & 0.91 \\
\hline Number of productive tillers & $15.4 \pm 1.2$ & $12.7-17.7$ & 1.5 & 0.5 & 4.7 & 7.9 & 0.35 \\
\hline Day to flowering (DAS) & $80.4 \pm 5.5$ & $71.3-92.8$ & 30.7 & 21.9 & 5.8 & 6.9 & 0.71 \\
\hline Day to harvesting (DAS) & $114 . \overline{2} \pm 4.0$ & $108.0-125.0$ & 16.2 & 10.5 & 2.8 & 3.5 & 0.65 \\
\hline Panicle length $(\mathrm{cm})$ & $28.5 \pm 2.1$ & $25.1-32.7$ & 4.6 & 3.7 & 6.8 & 7.7 & 0.80 \\
\hline Number of filled grains/panicle & $164.6 \pm 29.8$ & $121.3-255.3$ & 911.2 & 763.1 & 16.8 & 18.3 & 0.84 \\
\hline Number of unfilled grains/panicle & $47.2 \pm 16.0$ & $22.3-83.2$ & 264.7 & 199.0 & 29.9 & 34.5 & 0.75 \\
\hline Number of total grains/panicle & $211.8 \pm 41.3$ & $154.2-329.5$ & 1754.3 & 1516.8 & 18.4 & 19.8 & 0.86 \\
\hline Weight of 1000 grains $(\mathrm{g})$ & $26.2 \pm 2.0$ & $22.6-32.3$ & 4.6 & 3.9 & 7.7 & 8.2 & 0.86 \\
\hline Productivity (ton $\mathrm{ha}^{-1}$ ) & $4.8+0.5$ & $3.5-6.2$ & 0.3 & 0.0 & 3.0 & 11.3 & 0.07 \\
\hline
\end{tabular}

Note: S.D. $=$ standard deviation, $\sigma_{\mathrm{p}}^{2}$ : phenotypic variance, $\sigma_{\mathrm{g}}^{2}$ : genotypic variance, GCV: genotypic coefficient of variation, PCV: phenotypic coefficient of variation, $\mathrm{h}^{2}$ : broad-sense heritability, DAS: day after sowing.

\section{Analysis of phenotypic and genotypic correlations of doubled haploid lines}

The phenotypic correlation analysis and genotypic correlation results showed that there were differences in the correlation values between characters (Table 3). The results of the phenotypic correlation analysis showed that productivity had a positive and significant correlation with the weight of 1000 grains $\left(0.36^{*}\right)$. In general, the difference of both correlation values is that phenotypic correlation was influenced by genetic and environmental conditions. The large environmental influence on phenotypic correlation made the relationship between characters invisible so that genotypic correlation plays an important role. Characters that had genotypic correlation illustrate that these characters had a genetic relationship even though they were not seen in the phenotypic correlation.

The character of productivity had a significant and positive correlation with number of productive tillers ( $\mathrm{r}=$ $0.99 * *)$ and weight of 1000 grains $(\mathrm{r}=0.99 * *)$. Genotypic correlation described the relationship between characters more accurately because genetic factors play an important role compared to phenotype factors. Both of these characters had a correlation value close to 1 which means that the characters greatly influenced productivity. A positive correlation value indicated that the characters play an important role in productivity, in which that an increase in the value of the characters will be followed by an increase in productivity. The high value of genotypic correlation on the two characters indicated that these characters have a direct genetic effect on productivity. These findings were in line with Sabaori et al. (2008), Seyoum et al. (2012), Hidayatullah et al. (2018), and Alsabah et al. (2019) in selecting the adapted and high yielding rice. Besides, based on heritability value, number of productive tillers and weight of 1000 grains have moderate and high heritability, respectively. Therefore, based on the result, the number of productive tillers and weight of 1000 grains could be used as selection characters together with the productivity in selecting the adapted doubled haploid rice line under rainfed area.

\section{Selection of advanced doubled haploid lines}

The results of the main component analysis showed that the three main components that had eigenvalues above 1 provide a total diversity of $76 \%$ (Table 4). Selection is directed to get lines that have high productivity so that the characters that support productivity must be in line with the character of productivity. Principal component analysis (PCA) is a technique for reducing the dimensionality of big data, increasing interpretability and minimizing information loss (Jolliffe and Cadima 2016). Principal component value was used as weighted index to determine selection index. Based on Table 4, PC 3 was the best PC for selecting line, hence the productivity eigenvector in PC3 was the greatest. However, the NPT in PC3 has negative eigenvector so that it was the opposite direction to productivity. The desired model was that the two characters have the same direction. Selection was also not made in PC1 because productivity had low value of PC and weight of 1000 grain had opposite direction. The PC 2 was the chosen PC with consideration that the three characters had the same direction even though the vector value is negative. The negative value on PC only shows the absolute position of the direction of diversity (Jolliffe and Cadima 2016) so that the coefficient value can be used as a weight in the index without paying attention to the negative value. The value of PC 2 showed the character coefficient value of productive tillers (0.305), 1000 grain weight (0.546), and productivity (0.306). These selecting characters were in line with Sabouri et al. (2008), Hidayatullah et al. (2018), and Alsabah et al. (2019).

The PC eigenvector on the productivity character was almost the same as the number of productive tillers value and it was lower than weight of 1000 grain. This aimed to obtain lines that had high productivity or it has a greater economic value, meanwhile, other characters used in the selection are productivity supporting characters. So the character of productivity should be the greatest weighting than other characters. Sabouri et al. (2008) obtained an index based on the multivariate path analysis that the production character had a weighting three times greater than the weighting of other characters. Based on this, the weighting of the productivity character was made three 
times greater than the original weighting because productivity had the greatest important value compared to other characters. The value of the index coefficient is in accordance with the formula, namely Selection index $=(3 *$ 0.306 PRD) + $0.305 \mathrm{NPT}+0.546 \mathrm{WOG}$, where PRD was productivity, NPT was number of productive tiller and WOG was weight of 1000 gram grains. From the formula obtained, the weighted selection index was calculated. The resulting index values were then ranked and lines with the index value higher than check varieties' value were selected.

The index coefficient value showed that the CG-8-18-12 line had the highest index value of 4.04, while the CG-95-1-1 line had the lowest index value of-2.61 (Table 5). Based on the weighted selection index, there were 15 genotypes that have a better index than the check variety
Inpari 18 which was the check variety for rainfed lowland rice. The breeding of rainfed lowland rice must take into account the drought tolerance of a variety. Drought tolerance for rainfed lowland rice was based on the ability to regrow because drought in rainfed land is uncertain, so the ability to regrow a plant was needed. According to Akbar (2019), it was revealed that CG-11-35-1-1 was categorized as sensitive under drought screening at seedling stage. Based on this consideration, 14 lines were selected which had a higher index value than the check variety Inpari 18. These lines were CG-8-18-1-2, CG-8-181-1, CG-8-92-1-2, CG-12-30-1-2, CG-9-81-1-2, CG-9-621-1, CG-9-2-1-5, CG-9-53-1-3, CG-12-85-1-3, CG-9-53-11, CG-12-58-1-1, CG-12-85-1-2, CG-12-30-1-3, and CG-981-1-1.

Table 3 Phenotypic correlation (below diagonal) and genotypic correlation (above diagonal) between agronomic traits on doubled haploid lowland rice

\begin{tabular}{lllllllllll}
\hline & PH & NPT & DF & HA & PL & NFG & NUG & NTG & WOG & PRD \\
\hline PH & & $-0.57^{* *}$ & $0.64^{* *}$ & $0.63^{* *}$ & $0.81^{* *}$ & $0.51^{* *}$ & $0.58^{* *}$ & $0.58^{* *}$ & 0.29 & -0.01 \\
NPT & -0.30 & & $-0.35^{*}$ & -0.13 & $-0.69^{* *}$ & $-0.84^{* *}$ & $-0.79^{* *}$ & $-0.86^{* *}$ & 0.01 & $0.99^{* *}$ \\
DF & $0.54^{* *}$ & -0.28 & & $0.94^{* *}$ & $0.79^{* *}$ & $0.53^{* *}$ & $0.59^{* *}$ & $0.59^{* *}$ & 0.13 & $0.39^{*}$ \\
HA & $0.55^{* *}$ & -0.07 & $0.86^{* *}$ & & $0.74^{* *}$ & $0.37^{*}$ & $0.65^{* *}$ & $0.50^{* *}$ & 0.21 & $0.44^{* *}$ \\
PL & $0.68^{* *}$ & $-0.41^{*}$ & $0.58^{* *}$ & $0.51^{* *}$ & & $0.59^{* *}$ & $0.94^{* *}$ & $0.76^{* *}$ & 0.28 & $-0.99^{* *}$ \\
NFG & $0.49^{* *}$ & $-0.55^{* *}$ & $0.42^{* *}$ & 0.28 & $0.58^{* *}$ & & $0.71^{* *}$ & $0.97^{* *}$ & -0.21 & $-0.99^{* *}$ \\
NUG & $0.49^{* *}$ & $-0.38^{*}$ & $0.47^{* *}$ & $0.48^{* *}$ & $0.69^{* *}$ & $0.59^{* *}$ & & $0.87^{* *}$ & 0.07 & $-0.99^{* *}$ \\
NTG & $0.54^{* *}$ & $-0.54^{* *}$ & $0.48^{* *}$ & $0.39^{*}$ & $0.68^{* *}$ & $0.95^{* *}$ & $0.80^{* *}$ & & -0.12 & $-0.99^{* *}$ \\
WOG & 0.24 & -0.01 & 0.06 & 0.10 & 0.19 & -0.18 & 0.07 & -0.11 & & $0.99^{* *}$ \\
PRD & 0.11 & 0.24 & 0.09 & 0.01 & -0.21 & -0.18 & -0.33 & -0.25 & $0.36^{*}$ & \\
\hline
\end{tabular}

Note: PH: plant height, NPT: number of productive tillers, DF: day to flowering, HA: day to harvesting, PL: panicle length, NFG: number of filled grains per panicle, NUG: number of unfilled grains per panicle, NTG: number of total grains per panicle, WOG: weight of 1000 grains, PRD: productivity, **: significant at $\alpha 0.01$; * significant at $\alpha 0.05$.

Table 4. Eight principal components obtained from 10 agronomic characters

\begin{tabular}{|c|c|c|c|c|c|c|c|c|}
\hline Traits & PC1 & PC2 & PC3 & PC4 & PC5 & PC6 & PC7 & PC8 \\
\hline Plant height & -0.341 & -0.290 & 0.228 & -0.081 & 0.103 & -0.666 & 0.501 & -0.081 \\
\hline Number of productive tillers & 0.268 & -0.305 & -0.260 & -0.289 & 0.769 & 0.094 & 0.024 & 0.236 \\
\hline Day to flowering & -0.342 & -0.289 & -0.254 & -0.288 & -0.378 & 0.242 & -0.146 & 0.066 \\
\hline Day to harvesting & -0.309 & -0.379 & -0.405 & -0.261 & -0.126 & 0.133 & 0.139 & -0.068 \\
\hline Panicle length & -0.388 & -0.101 & 0.065 & 0.133 & 0.160 & -0.353 & -0.731 & 0.338 \\
\hline Number of filled grains per panicle & -0.355 & 0.329 & 0.275 & -0.217 & 0.105 & 0.278 & 0.228 & 0.434 \\
\hline Number of unfilled grains per panicle & -0.379 & 0.100 & -0.129 & 0.234 & 0.389 & 0.163 & -0.117 & -0.694 \\
\hline Number of total grains per panicle & -0.403 & 0.276 & 0.148 & -0.066 & 0.227 & 0.263 & 0.119 & 0.043 \\
\hline Weight of 1000 grains & -0.056 & -0.546 & 0.261 & 0.651 & 0.023 & 0.378 & 0.160 & 0.198 \\
\hline Productivity & 0.122 & -0.306 & 0.683 & -0.460 & 0.001 & 0.177 & -0.261 & -0.322 \\
\hline Proportion of variance & 0.49 & 0.15 & 0.11 & 0.10 & 0.06 & 0.04 & 0.03 & 0.02 \\
\hline Cumulative of variance & 0.49 & 0.64 & 0.76 & 0.85 & 0.91 & 0.94 & 0.97 & 0.99 \\
\hline Eigenvalue & 4.94 & 1.46 & 1.15 & 0.96 & 0.57 & 0.37 & 0.25 & 0.22 \\
\hline
\end{tabular}


Table 5. Weighted selection index of 35 doubled haploid rice and 2 check varieties

\begin{tabular}{|c|c|c|c|c|}
\hline Genotype & NPT & WOG & PRD & $\begin{array}{c}\text { Weighted } \\
\text { index }\end{array}$ \\
\hline CG-8-18-1-2\# & 17.7 & 30.4 & 6.2 & 4.04 \\
\hline CG-8-18-1-1\# & 15.2 & 32.3 & 5.5 & 2.80 \\
\hline CG-8-92-1-2\# & 16.6 & 27.6 & 5.2 & 1.39 \\
\hline CG-12-30-1-2\# & 15.7 & 27.1 & 5.3 & 1.18 \\
\hline CG-9-81-1-2\# & 14.0 & 26.2 & 5.7 & 1.14 \\
\hline CG-9-62-1-1\# & 16.0 & 26.2 & 5.3 & 1.02 \\
\hline CG-9-2-1-5\# & 17.2 & 24.4 & 5.4 & 1.00 \\
\hline CG-9-53-1-3\# & 17.3 & 25.3 & 5.1 & 0.79 \\
\hline CG-12-85-1-3\# & 14.9 & 25.6 & 5.4 & 0.74 \\
\hline CG-9-53-1-1\# & 15.4 & 25.3 & 5.3 & 0.62 \\
\hline CG-12-58-1-1\# & 14.9 & 27.3 & 5.0 & 0.56 \\
\hline CG-11-35-1-1 & 16.8 & 24.7 & 5.1 & 0.50 \\
\hline CG-12-85-1-2\# & 14.4 & 26.1 & 5.2 & 0.43 \\
\hline CG-12-30-1-3\# & 14.1 & 27.4 & 5.0 & 0.38 \\
\hline CG-9-81-1-1\# & 14.0 & 27.0 & 5.0 & 0.26 \\
\hline Inpari 18 & 16.0 & 29.0 & 4.3 & 0.18 \\
\hline Ciherang & 17.0 & 26.3 & 4.6 & 0.18 \\
\hline CG-8-9-1-2 & 16.3 & 26.9 & 4.6 & 0.17 \\
\hline CG-7-72-1-6 & 15.6 & 27.7 & 4.5 & 0.05 \\
\hline CG-8-93-1-1 & 15.8 & 24.6 & 4.9 & -0.09 \\
\hline CG-9-53-1-2 & 16.1 & 24.2 & 4.9 & -0.14 \\
\hline CG-8-92-1-1 & 14.8 & 27.5 & 4.5 & -0.20 \\
\hline CG-11-69-1-1 & 14.5 & 24.4 & 5.0 & -0.31 \\
\hline CG-8-35-1-2 & 16.0 & 25.9 & 4.5 & -0.34 \\
\hline CG-8-9-1-4 & 15.2 & 27.7 & 4.3 & -0.36 \\
\hline CG-8-9-1-3 & 15.2 & 27.0 & 4.2 & -0.72 \\
\hline CG-9-2-1-6 & 15.1 & 24.2 & 4.6 & -0.86 \\
\hline CG-9-26-1-5 & 15.9 & 23.4 & 4.6 & -0.89 \\
\hline CG-9-26-1-2 & 17.7 & 23.9 & 4.2 & -0.92 \\
\hline CG-12-71-1-1 & 13.2 & 23.8 & 4.9 & -0.97 \\
\hline CG-7-72-1-5 & 12.7 & 28.2 & 4.2 & -1.03 \\
\hline CG-7-72-1-2 & 13.6 & 28.1 & 4.0 & -1.14 \\
\hline CG-7-72-1-7 & 13.8 & 27.3 & 4.1 & -1.15 \\
\hline CG-9-53-1-4 & 15.3 & 24.8 & 4.0 & -1.60 \\
\hline CG-8-9-1-5 & 15.3 & 24.8 & 4.0 & -1.60 \\
\hline CG-9-26-1-6 & 14.8 & 22.6 & 3.9 & -2.50 \\
\hline CG-9-5-1-1 & 15.9 & 23.5 & 3.5 & -2.61 \\
\hline
\end{tabular}

Note: \#: selected lines, NPT: number of productive tillers, WOG: weight of 1000 grains (g), PRD: productivity (ton ha ${ }^{-1}$ )

To summary, according to the study, we concluded that there were fourteen selected lines with good agronomic characteristics, i.e. number of productive tillers (14.0-17.7 tillers), weight of 1000 grains $(24.4-32.3 \mathrm{~g})$, and productivity (5.0-6.2 ton ha $\left.{ }^{-1}\right)$. These selected lines can be evaluated in multi locations to test for their performance and stability.

\section{ACKNOWLEDGEMENTS}

We wish to thank Ministry of Research, Technology, and Higher Education, Republic of Indonesia for funding the research through PMDSU research grant fiscal year of 2017 (136/SP2H/LT/DRPM/2017) to Bambang Sapta Purwoko and team and for PMDSU scholarship to Miftahur Rizqi Akbar. The authors also wish to express their gratitude to IPB and Indonesian Center for Rice Research for facilitating the research.

\section{REFERENCES}

Abebe T, Alamerew S, Tulu L. 2017. Genetic variability, heritability and genetic advance for yield and its related traits in rainfed lowland rice (Oryza sativa L.) genotype at Fogera and Pawe, Ethiopia. Adv Crop Sci Tech 5 (272):10-4172. DOI: 10.4172/2329-8863.1000272

Abhilash R, Thiruvengadam T, Dhatchinamoorthy S, Chitra S. 2018. Genetic studies in F2 for biometrical traits in rice (Oryza sativa. L). Electronic J Plant Breed 9 (3): 1067-1076. DOI: 10.5958/0975928X.2018.00133.3.

Akbar MR. 2019. Breeding of Doubled-Haploid Rainfed Rice Lines Derived from Anther Culture Tolerant to Drought. [Dissertation]. IPB University, Bogor. [Indonesian]

Akbar MR, Purwoko BS, Dewi IS, Suwarno WB. 2018. Agronomic and drought tolerance evaluation of doubled haploid rice breeding lines derived from anther culture. SABRAO J Breed Genet 50 (2):115-128.

Akbar MR, Purwoko BS, Dewi IS, Suwarno WB. 2019. Selection of doubled haploid lines of rainfed lowland rice in preliminary yield $\begin{array}{lllll}\text { trial. } & \text { Biodiversitas } 20 & \text { (10): 2796-2801. DOI: }\end{array}$ 10.13057/biodiv/d201003.

Al-kordy MA, Ibrahim HF, El-Mouhamady AB, Abdel-Rahman HM. 2019. Genetic stability analysis and molecular depiction in elite entries of rice (Oryza sativa L.). Bull Natl Res Cent. DOI: 10.1186/s42269-019-0100-3.

Alsabah R, Purwoko BS, Dewi IS, Wahyu Y. 2019. Selection index for selecting promising doubled haploid lines of black rice. SABRAO J Breed Genet 51 (4): 430-441.

Anshori MF, Purwoko BS, Dewi IS, Ardie SW, Suwarno WB. 2019. Selection index based on multivariate analysis for selecting doubledhaploid rice lines in lowland saline prone area. SABRAO J Breed Genet 51 (2): 161-174.

Cui Y, Li R, Li G, Zhang F, Zhu T, Zhang Q, Ali J, Li Z, Xu S. 2020. Hybrid breeding of rice via genomic selection. Plant Biotech J. 2020 Jan;18(1):57-67. DOI: 10.1111/pbi.13170.

Dewi IS, Syafii M, Purwoko BS, Suwarno WB. 2017. Efficient indica rice anther culture derived from three-way crosses. SABRAO J Breed Genet 49(4):336-345

Dwivedi SL, Britt AB, Tripathi L, Sharma S, Upadhyaya HD, Ortiz R. 2015. Haploids: constraints and opportunities in plant breeding. Biotechnol Adv 33: 812-829. DOI: 10.1016/j.biotechadv.2015.07.001

Erythrina E, Anshori A, Bora CY, Dewi DO, Lestari MS, Mustaha MA, Ramija KE, Rauf AW, Mikasari W, Surdianto Y, Suriadi A. 2021. Assessing opportunities to increase yield and profit in rainfed lowland rice systems in Indonesia. Agronomy 11 (4):777. DOI: 10.3390/agronomy11040777.

Fadhli N, Farid M, Rafiuddin, Efendi R, Azrai M, Anshori MF. 2020. Multivariate analysis to determine secondary characters in selecting adaptive hybrid corn lines under drought stress. Biodiversitas. 21(8): 3617-3624. DOI: 10.13057/biodiv/d210826.

Farid M, Nasaruddin YM, Ridwan I, Anshori MF. 2021. Effective screening of tropical wheat mutant lines under hydroponically induced drought stress using multivariate analysis approach. Asian J Plant Science. 20:172-182. DOI: 10.3923/ajps.2021.172.182.

GRiSP (Global Rice Science Partnership). 2013. Rice almanac, 4th ed. International Rice Research Institute, Los Baños, Philippines.

Hasan R, Akand M, Alam N, Bashar A, Huque AKMM. 2016. Genetic association analysis and selection indices for yield attributing traits in available chilli (Capsicum annum L.) genotypes. Mol Plant Breed 7: 1-9. DOI: $10.5376 / \mathrm{mpb} .2016 .07 .0019$.

Hidayatullah A, Purwoko BS, Dewi IS, Suwarno WB. 2018. Agronomic performance and yield of doubled haploid rice lines in advanced yield trial. SABRAO J Breed Genet 50 (3): 242-53.

Islam MR, Kayess MO, Hasanuzzaman M, Rahman MW, Uddin MJ, Zaman MR. 2017. Selection index for genetic improvement of wheat (Triticum aestivum L.). J Chem Biol Phys Sci 7(1):1-8. DOI: 10.9734/IJPSS/2017/31046.

IRRI [International Rice Research Institute]. 2015. Rice Production Manual. International Rice Research Institute, Los Baños, Philippines. 
Janmohammadi M, Movahedi Z, Sabaghnia N. 2014. Multivariate statistical analysis of some traits of bread wheat for breeding under rainfed conditions. J Agric Sci 59 (1): 1-14. DOI: 10.2298/JAS1401001J

Jiang N, Yan J, Liang Y, Shi Y, He Z, Wu Y, Zeng Q, Liu X, Peng J. 2020. Resistance genes and their interactions with bacterial blight/leaf streak pathogens (Xanthomonas oryzae) in rice (Oryza sativa L.) —an updated review. Rice 13 (1): 1-12. DOI: 10.1186/s12284-019-0358-y.

Jolliffe IT, Cadima J. 2016. Principal component analysis: a review and recent developments. Phil Trans R Soc A 374:20150202. DOI 10.1098/rsta.2015.0202.

Kose A, Onder O, Bilir O, Kosar F. 2018. Application of multivariate statistical analysis for breeding strategies of spring safflower (Carthamus tinctorius L.). Turk J Field Crops 23:12-19. DOI: $10.17557 /$ tjfc. 413818 .

Ministry of Agriculture Republic of Indonesia. 2019. Agricultura Statistics 2019. Center for Agricultural Data and Information System, Jakarta. [Indonesian]

Mishra R, Rao GJ, Rao RN, Kaushal P. 2015. Development and characterization of elite doubled haploid lines from two indica rice hybrids. Rice Sci 22 (6): 290-299. DOI: 10.1016/j.rsci.2015.07.002.

Nirmaladevi G, Padmavathi G, Kota S, Babu VR. 2015. Genetic variability, heritability and correlation coefficients of grain quality characters in rice (Oryza sativa L.). SABRAO J Breed Genet 47 (4): 424-433.

Ogunbayo SA, Sié M, Ojo DK, Sanni KA, Akinwale G, Toulou B, Shittu A, Idehen EO, Popoola AR, Daniel IO, Gregorio GB. 2014. Genetic variation and heritability of yield and related traits in promising rice genotypes (Oryza sativa L.). J Plant Breed Crop Sci 6 (11): 153-159. DOI: 10.5897/JPBCS2014.0457.

Oladosu Y, Rafii MY, Magaji U, Abdullah N, Miah G, Chukwu SC, Hussin G, Ramli A, Kareem I. 2018. Genotypic and phenotypic relationship among yield components in rice under tropical conditions. BioMed Res Intl 2018: 8936767. DOI: $10.1155 / 2018 / 8936767$.

Sabouri H, Rabiei B, Fazlalipour M. 2008. Use of selection indices based on multivariate analysis for improving grain yield in rice. Rice Sci 15 (4): 303-310. DOI: 10.1016/S1672-6308(09)60008-1.

Sandhu SK, Kang MS, Akash MW, Singh P. 2019. Selection indices for improving selection efficiency in Indian mustard. J Crop Improv 33 (1): 25-41. DOI: 10.1080/15427528.2018.1539689.

Seyoum M, Alamerew S, Bantte K. 2012. Genetic variability, heritability, correlation coefficient and path analysis for yield and yield-related traits in upland rice (Oryza sativa L.). J Plant Sci 7 (1): 13-22. DOI: 10.3923/jps.2012.13.22

Silva LA, Resende RT, Ferreira RADC, Silva GN, Kist V, Barbosa MHP, Nascimento $M$ and Bhering LL. 2016. Selection index using the graphical area applied to sugarcane breeding. Genet Mol Res 15 (3): gmr.15038711. DOI: 10.4238/gmr.15038711.

Tuhina-Khatun M, Hanafi MM, Rafii Yusop M, Wong MY, Salleh FM, Ferdous J. 2015. Genetic variation, heritability, and diversity analysis of upland rice (Oryza sativa L.) genotype based on quantitative traits. BioMed Res Int 2015: 290861. DOI: 10.1155/2015/290861.

Villa JE, Henry A, Xie F, Serraj R. 2012. Hybrid rice performance in environments of increasing drought severity. Field Crops Res 125: 14-24. DOI: 10.1016/j.fcr.2011.08.009. 